\section{Viktig oppdatering av allerede glimrende bok om lungesykdommer}

Giæver P.

Lungesykdommer

2. utg. 252 s, ill. Oslo: Universitetsforlaget, 2008.

Pris NOK 399

ISBN 978-82-15-01152-3

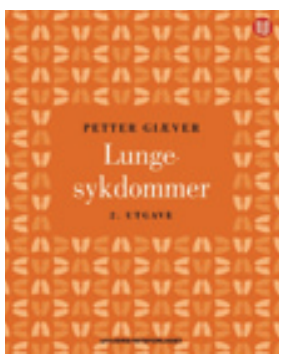

Petter Giævers glimrende bok om lungesykdommer som ble lansert i 2002, er kommet i ny og oppdatert utgave. Målgruppen er helsepersonell som behandler personer med lungesykdommer samt medisinstudenter og fysioterapistudenter. Som tidligere er det 21 kapitler, hvor man innledningsvis konsentrerer seg om lungenes struktur og funksjon, samt tolking av symptomer og tegn. Videre finnes det kapitler om atelektase, respirasjonssvikt, astma, kols, bronkiektasier, cystisk fibrose, interstitiell lungesykdom, pulmonal vaskulitt og eosinofil pneumoni, pneumonier, lungeabscess, pleurasykdommer, tuberkulose, lungekreft, lungeemboli, pulmonal hypertensjon, lungeødem og akutt lungesviktsyndrom (ARDS), sjeldne lungesykdommer og lungetransplantasjon. I flere kapitler gis god innsikt i patofysiologiske mekanismer og respirasjonsfysiologi. Nytt i denne utgaven er bl.a. viktig oppdatert informasjon om legionellapneumonier, medikamentell og infeksiøst (hiv) betinget immunsuppresjon, opportunistiske infeksjoner, pulmonale arteriovenøse malformasjoner og røykeavvenning. De fleste røntgen- og CTbilder fra forrige utgave er skiftet ut med meget gode eksempler. Bildediagnostikkens betydning er også gjennomgående bedre vektlagt, og en del figurer og tabeller er byttet ut eller betydelig oppdatert og forbedret. Temaer som bevisst fremdeles ikke er videre omtalt, er obstruktiv søvnapné, allergi og detaljer rundt tekniske prosedyrer.

Disposisjonen av stoffet er som tidligere logisk, med en meget god pedagogisk tilnærming, språket er godt og layouten er forbedret med bl.a. markering av tekst, som kun er for spesielt interesserte. Antall refe- ranser er økt med ca. 100 til 386, og det er med flere norske henvisninger enn forrige gang.

Petter Giæver viser fortsatt at han både har bred klinisk erfaring og solid teoretisk bakgrunn, og man er gjennomgående trygg på det som er hans egne tolkinger og meninger. Oppdateringene er både viktige og presise. Fordi boken skal brukes i mange år fremover, skulle man ønsket at deadline hadde vært på forfatterens side når det gjelder den nye kontrollfokuserte klassifikasjonen av astma, jf. Global Initiative for Asthma, slik at man slapp den gamle inndelingen $\mathrm{i}$ intermitterende, mild persisterende, moderat persisterende og alvorlig persisterende astma (s. 64, 66). På den annen side er TNM-klassifikasjonen helt oppdatert, til og med med foreslåtte endringer som vil gjelde fra 2009. I denne nye utgaven er også nomenklaturen oppdatert, for eksempel slik at NPPV nå heter NIV (non-invasiv ventilasjon). I omtale av BiPAP er en liten men viktig praktisk opplysning falt ut i ny utgave, nemlig at trykket anbefales økt med $2 \mathrm{~cm} \mathrm{H}_{2} \mathrm{O}$ om gangen. Jeg savner også, når fysiologiske effekter av NIV er så godt forklart, noe mer konkret informasjon om hvordan man styrer en BiPAP avhengig av om man ønsker en forebedret $p \mathrm{O}_{2}$ og/eller $p \mathrm{CO}_{2}$.

Boken er som tidligere viktig for enhver som ønsker å få en solid innføring i lungemedisin. Den kan leses av sykepleiere og fysioterapeuter som jobber eller utdanner seg i faget, og vil være utmerket for enhver medisinstudent, men også en meget verdifull basis for spesialistkandidater i lungemedisin. Den bør også med stort utbytte kunne leses av erfarne lungeleger som ønsker å holde seg bredt oppdatert i faget. Denne boken konkurrerer klart med en annen ny norsk bok i lungemedisin av professorene Amund Gulsvik \& Per S. Bakke ved Universitetet i Bergen.

Hvis Petter Giæver arbeider videre med en ny versjon, kan man kanskje kikke litt til de foreslåtte fem nye obligatoriske kurs $i$ lungemedisin som snart vil gjelde. Ett av disse kursene er i lungerelatert intensivmedisin, særlig med vekt på NIV og respiratorbehandling. Jeg tror dermed et eget kapittel, som favner dette egne fagfeltet opp mot anestesifaget, vil kunne bli nyttig for mange lesere i fremtiden. Obstruktiv søvnapné (OSA) øker kraftig pga. økende vekt $i$ befolkningen og er en utfordring ved de fleste lungemedisinske seksjoner i Norge.
Kanskje bortsett fra enkel CPAP ved obstruktiv søvnapné, så bør BiPAP ved kols og kronisk respirasjonssvikt og mer avansert ventilasjonsstøtte ved Cheyne-Stokes' respirasjon ved for eksempel hjertesvikt, i fremtiden helst ivaretas av lungeleger. På samme måte er også allergi og allergivaksinering noe som de fleste lungemedisinere må håndtere $\mathrm{i}$ dag, og en omtale av dette området hører etter mine vurderinger hjemme i en lungemedisinsk lærebok. I en ny utgave ville jeg også påsett at indekseringen ble mer omfattende. Med egne overskrifter som «Non-invasiv mekanisk ventilasjon», ville jeg forventet å finne dette igjen i indeksen under «N» eller «V». På samme måte savnes for eksempel strålebehandling, cytostatika, røykeavvenning, pasientopplæring, rehabilitering etc. i stikkordslisten.

Men hovedkonklusjonen er igjen som sist: Meget godt levert av en solid kollega.

\section{Frode Gallefoss}

Seksjon for lungesykdommer

Sørlandet sykehus

Kristiansand

\section{Debattinnlegg om kjønnslemlesting}

Strand T.

\section{Suaads reise}

En dokumentar om kjønnslemlestelse. $291 \mathrm{~s}$ Oslo: NRK Aktivum, 2008. Pris NOK 349 ISBN 978-82-8178-277-8

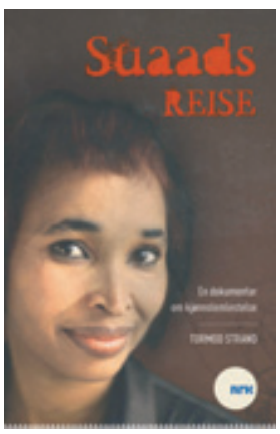

I slutten av juni 2007 sendte NRK noen reportasjer i Dagsrevyen, som fikk mange til å våkne. Det var spesielt skrikene til den åtte år gamle Anisa fra Somalia som vakte oppsikt. Journalist Tormod Strand sto utenfor på gangen med kamera og mikrofon mens Anisa ble kjønnslemlestet. Denne episoden førte til at han skrev bok om kjønnslemlesting.

Utgangspunktet er den norsksomaliske Suaad Abdi Farahs historie om sin egen kjønnslemlesting. 7000 jenter i Norge er 
fra risikoland, dvs. land der tradisjonen står sterkt, spesielt Somalia, Eritrea, Etiopia og Gambia. Alder for kjønnslemlesting er fra ett år til 7-8 år, men også opp til 14-15 år forekommer. WHO regner med at om lag to millioner jenter omskjæres hvert år på verdensbasis. Suaads opplevelse deles med andre ord av millioner av kvinner.

Suaad er utdannet jordmor fra Somalia og har selv møtt mange ofre for kjønnslemlesting. Vanligvis brukes usteriliserte kniver eller barberblad. Følgen kan være at mange av jentene dør av infeksjon eller blodtap, spesielt dersom pulsåren i klitoris kuttes. Helseproblemer og store smerter, etter å ha fått skåret bort en del av kjønnsorganet og blitt sydd igjen, er vanlig som voksen kvinne. Mange har bare $1 \mathrm{~cm}$ åpning nedentil, der både menstruasjonsblod og urin skal passere. Det kan bygge seg opp vev og cyster rundt rester av blod og urin inne i skjeden. For kvinner som er kjønnslemlestet kan det også være større risiko for hivsmitte, fordi samleie kan føre til økt friksjon og blødninger.

Selv om mye er endret nå, er Suaads møte med norsk helsevesen i slutten av 1980-årene interessant lesing. Suaad har hatt fire barnefødsler i Norge, og hver gang ble hun sydd igjen (noe som er forbudt å gjøre i Norge nå) til tross for at hun ba om at det ikke ble gjort: «Hun var trolig blant de første omskårne somaliske kvinnene som fødte på et norsk sykehus, derfor er det kanskje ikke så rart at kunnskapene var mangelfulle... Men utover 90-tallet kom det hundrevis av somaliske kvinner som skulle føde på norske sykehus. ... Det gjorde fødsler for mange somaliske kvinner i Norge til en traumatisk opplevelse».

Kjønnslemlesting har en lang historisk forklaring. Å «bli renset», eller rengjort, blir sett som en del av det å bli voksen. I enkelte deler av verden er et kvinnelig kjønnsorgan som er nesten helt lukket, betraktet som vakkert. Det heter at de «pynter på kvinnens kjønnsorganer». Suaad forteller i boken: «Jeg trodde alle kvinner i resten av verden var omskåret. Når jeg kom til Norge og oppdaget at dette ikke var tilfelle, fikk jeg sjokk. I Europa er en omskåret kvinne det samme som en lemlestet kvinne.»

Hvorfor gjøres dette mot kvinner? Det finnes ingen religiøse krav om å kjønnslemleste, men det begrunnes med at alle gjør det. Det handler om å ikke skille seg ut fra mengden. Kvinner som ikke er omskåret, kan dermed stå i fare for ikke å «bli gift».

1.1. 1996 ble loven mot omskjæring vedtatt, men den har ennå ikke blitt brukt her i Norge. Forbudet gjelder selv om barn blir tatt med til utlandet og lemlestingen foregår utenfor Norges grenser. Loven fikk et tillegg i 2004, nemlig at ansatte innen helsevesen, skole, barnehager og barnevern risikerer straff hvis de ikke prøver å stoppe en planlagt kjønnslemlesting som de făr kjennskap til (avvergelsesplikten). Forfatteren skriver: «Hvis du hadde kuttet av hånden til barnet ditt, ville du sannsynligvis blitt straffet for det. Hvis du kutter bort en del av kjønnsorganet til barnet ditt, er det ikke gitt at det vil fă noen følger.»

Suaads reise er et dagsaktuelt innlegg i debatten om helseundersøkelser av jenters underliv. Til tross for at dette er et betent tema, er drøftingsdelen nyansert. Det fremste budskapet er at jenter skal sikres rettigheten til å beholde sin kropp slik den er skapt fra fødselen av. Alle barn - uansett hudfarge - bør ha samme rettigheter - uansett hvor i verden de befinner seg.

Det gis et godt innblikk både $\mathrm{i}$ hva kjønnslemlesting faktisk er, følgene av å bli utsatt for dette samt årsaken til det. Til tider kan beskrivelsene av fakta rundt kjønnslemlesting virke såpass overveldende, at $\mathrm{i}$ hvert fall denne leseren måtte legge fra seg boken flere ganger underveis. Mange yrkesgrupper, deriblant helsepersonell, kan ha stort faglig utbytte av å lese Suaads reise.

\section{Lis Karin Andersen}

Utvikling og integrering

Vox - Nasjonalt senter for læring i arbeidslivet Oslo

\section{Siste nytt fra schizofrenifronten}

Hall H, Hall E, red.

\section{Schizophrenia}

Modern concepts and research findings. $195 \mathrm{~s}$, ill. Lund: Studentlitteratur, 2008. Pris SEK 258 ISBN 978-91-44-02980-1

Vår forståelse av årsaker og sykdomsmekanismer ved schizofreni er langt fra fullstendig. Tusentalls forskere over hele verden er engasjert $\mathrm{i}$ forsøket på å forstå sykdommen, og håpet er at forskningen skal bidra til å utvikle mer målrettede og effektive behandlingsformer.

Schizophrenia-modern concepts and research findings gir en oppdatert oversikt over status innen sentrale områder av schizofreniforskningen. De ni kapitlene omhandler hvert sitt spesifikke tema: klinikk, genetikk, epidemiologi, nevropsykologi, avbildning av hjernefunksjon, avbildning av hjernestruktur, hjernens kjemi, tidlig oppdagelse og intervensjon ved psykose, og psykofarmakologi. Hvert kapittel inneholder en referanseliste og forslag til videre lesing, noe som er svært nyttig for dem som ønsker målrettet fordypning. Sist i boken er det en seksjon med forkortelser, en figur over hjernens viktigste bestanddeler, stikkordregister og illustrasjoner.

Seks av de åtte bidragsyterne er tilknyttet Karolinska Institutet i Stockholm som i en årrekke har vært ledende innen schizofreniforskning. Hver forfatter har særlig vektlagt sitt kompetansefelt, og det er i liten grad kryssreferanser mellom kapitlene. Temaene blir grundig behandlet, men ulike forfatterstemmer gir fremstillingen et noe fragmentert inntrykk.

Noe av stoffet kan være vanskelig tilgjengelig for uinnvidde, spesielt kapitlet om hjernens kjemi. Her omhandles eksperimentelle prekliniske studier som i liten grad er knyttet til klinisk forståelse og behandling av schizofreni. Andre kapitler er mer klinikknære, slik som Göran Sedvalls oversiktlige gjennomgang av klinisk og farmakologisk behandling, og Ingrid Melles godt skrevne kapittel om tidlig oppdagelse og intervensjon ved psykose.

Tittelen gir bud om en beskrivelse av moderne forståelse av schizofreni, men dette er fraværende i teksten. Et kapittel om sentrale forklaringsmodeller, slik som nevro-utviklingshypotesen, ville være nyttig for å tilby leseren en mer helhetlig vitenskapelig ramme for sykdommen. Noen sentrale områder er heller ikke dekket, slik som funn fra nevropatologiske og nevrofysiologiske studier. Dermed kan ikke boken sies å gi en fullstendig oppdatering av schizofreniforskningen.

Boken er gjennomgående godt skrevet på et lettfattelig engelsk. Myke permer, A5format og luftige sider bidrar til et leservennlig oppsett.

Helsearbeidere, studenter og forskere angis som målgruppe for tekstene. Hensikten er å bedre helsetjenesten og behandlingen av pasienter med schizofreni. Hvorvidt innholdet er av direkte nytteverdi for klinikere er usikkert. Tekstene er fokusert på forskningsdata og vil i hovedsak være verdifulle for helsearbeidere og studenter med interesse for schizofreni utover praktisk klinisk behandling. Boken kan også anbefales for leger og forskere som ønsker en kortfattet oversikt over status på schizofrenifronten.

\section{Ragnar Nesvåg}

Distriktspsykiatrisk senter Vinderen

Diakonhjemmet sykehus

Oslo

\section{Rammet av slag}

\section{Cromarty $\mathrm{M}$.}

\section{Stroke - it couldn't happen to me}

One woman's story of surviving a brain-stem stroke. 119 s. Oxon: Radcliffe, 2008. Pris GBP 15 ISBN 978-1-84619-295-1

Denne boken er en blant flere bøker i en serie med pasienters fortellinger om egen sykdom. Stroke - it couldn't happen to me handler om å bli rammet av et alvorlig hjerneslag midt i livet. Margaret Cromarty var 43 år gammel da hun under en gudstjeneste merket at hun ble svimmel. Kort tid etterpå befinner hun seg $\mathrm{i}$ en intensivenhet og er ute av stand til å bevege noe annet enn øynene. 